\title{
Electrocardiogram Collection Date Time
}

National Cancer Institute

\section{Source}

National Cancer Institute. Electrocardiogram Collection Date Time. NCI Thesaurus. Code C83256.

The date and time of an electrocardiogram. 